Vol. 8, Issue 2, December, 2020

E-ISSN 2722-4708 P-ISSN 2302-3783

DOI: $10.20961 /$ bestuur.42774

This work is licensed under a Creative Commons Attribution 4.o International License (cc-by)

\title{
Discourse on Creating a Special Environmental Court in Indonesia to Resolve Environmental Disputes
}

\author{
Suwari Akhmaddhian \\ Faculty of Law, Universitas Kuningan, Indonesia \\ Email Coresponden: suwari_akhmad@uniku.ac.id
}

\begin{abstract}
The purpose of this study is to determine the regulation of laws and regulations regarding environmental justice in Indonesia and how the concept of building environmental justice in the justice system in Indonesia. This research can be useful both practically and theoretically, practically. The research method used by researchers is the evaluative analysis method, which is a method of gathering and presenting data obtained to analyze the actual situation and then rational analysis is carried out based on juridical references through library research. The results of the research Regulations on the environment are already available namely Law Number 32 of 2009 concerning Environmental Protection and Management and building an environmental justice system starting from improving human resources namely the Supreme Court by consistently educating and training judges with knowledge of aspects of environmental law life that will later handle environmental cases; The Supreme Court makes a special assembly that handles environmental cases; The Supreme Court creates a special chamber that is integrated with the general court that handles environmental cases; The government is amending the 1945 Constitution specifically Article 24 by adding the judicial environment to the environmental court. The conclusion of the legislation is already available and must be used as well as possible and amend the laws and regulations so that bias can be created specifically for environmental justice.
\end{abstract}

Keywords: Building; Environmental; Justice System.

\begin{abstract}
Abstrak
Tujuan penelitian ini adalah untuk mengetahui regulasi peraturan perundangan-undangan tentang peradilan lingkungan di Indonesia dan bagaimana konsep membangun peradilan lingkungan pada sistem peradilan di Indonesi. Penelitian ini dapat berguna secara praktis dan teoritis, secara praktis. Metode penelitian yang digunakan oleh peneliti adalah metode evaluative analisis, yaitu suatu metode mengumpulkan dan menyajikan data yang diperoleh untuk menganalisis keadaan yang sebenarnya dan selanjutnya dilakukan analisis rasional berdasarkan acuan yuridis melalui penelitian kepustakaan. Hasil penelitian Peraturan tentang lingkungan hidup sudah tersedia yaitu Undang-undang Nomor 32 tahun 2009 tentang Perlindungan dan Pengelolaan Lingkungan Hidup dan membangun system peradilan lingkungan mulai dari peningkatan sumber daya manusia yaitu Mahkamah Agung dengan konsisten mendidik dan melatih hakim dengan pengetahuan tentang aspekaspek hukum lingkungan hidup yang nantinya akan menangani kasus-kasus lingkungan hidup; Mahkamah Agung membuat majelis khusus yang menangani kasus-kasus lingkungan hidup; Mahkamah Agung membuat kamar khusus yang menyatu dengan peradilan umum yang menangani kasus-kasus lingkungan hidup; Pemerintah dengan mengamandemen UUD 1945 khususnya Pasal 24 dengan menambah lingkungan peradilan dengan pengadilan lingkungan. Simpulan peraturan perundang-undangan sudah tersedia dan harus dimanfaatkan dengan sebaik-baiknya dan mengamandemen peraturan perundanganundangan agar bias tercipta secara khusus peradilan lingkungan.
\end{abstract}

Kata Kunci: Membangun; Sistem Peradilan Lingkungan. 


\section{Introduction}

The enforcement process has an impact on the justice system. A good judicial system will affect the implementation of applicable laws and regulations, environmental law enforcement is closely linked to all aspects of human life because the environment is a buffer for the life of living things on this earth. Constitutionally embedded in Article $28(\mathrm{~h})(\mathrm{l})$ which reads 'every person lives in physical and mental prosperity, lives and obtains a good and stable environment and receives health services' and Article 33(3) which reads 'Earth and water and the natural resources found therein are regulated by the State and used for the greater prosperity of the people'

The constitutional provisions on Indonesia's judicial system, namely Article 24, which includes an autonomous judicial authority consisting of general courts, religious courts, military courts, and state administrative tribunals. It is still possible to have special judicial bodies in each of those judicial settings, such as commercial courts, which are included in the general court system. Independence in the exercise of power is needed for the exercise of independent judicial power. There must be no intervention from other branches of power such as the executive or legislative branches and the existence of legal certainty and guarantees of protection of human rights regardless of gender, cultural background, economic conditions and political views (Adi Sulistiyono, 2006, 596o).

Regulations relating to the environment are Law Number 32 of 2009 concerning Environmental Protection and Management, Law Number 05 of 1990 concerning Conservation of Living Natural Resources and Ecosystems, Law Number 41 of 1999 concerning Forestry. Law Number 32 of 2009 concerning Environmental Protection and Management regulates sanctions for proven parties that violate law enforcement in the field of environment can be classified into 3 (three) categories, namely: 1). Environmental law enforcement applied to the Regulatory Law of the State, 2). Enforcement of Civil Law related to environmental law, 3). Enforcement of Criminal Law related environmental law. Legal development must strike a balance between public and private interests (Lego Karjoko, Zaidah Nur Rosidah I Gusti Ayu Ketut Rahmi Handayani, 2019: 1213)

The main problems in the environment identified were 5 (five) including (Nana Sudiana and Hasmana Soewandita, 2007,44-51): 1) land damage due to deforestation, illegal logging, land conversion for plantations and industrial plants, oil mining, industry and settlement; 2 ) riverbank abrasion due to shipping traffic of large and fast ships; 3) silting of rivers by high erosion, abrasion and sedimentation; 4) disruption of surface water flow patterns due to land use change, the presence of ports, docks, and logponds; 5) deterioration in water quality due to industrial wastewater discharges, domestic ballast water disposal, and domestic solid waste discharges. It is predicted then that the presence of this research will be able to measure and know the justice system in Indonesia.

The medical, technological, planological, environmental, economic, and legal aspects of this environmental problem can be examined. This has been 
stated by Siti Sundari Rangkuti, namely the legal aspects of environmental management and natural resource conservation in Indonesia need to be intensively studied, since environmental management is not possible without legal arrangements. This does not mean that legal experts can handle environmental issues, regardless of other environmental disciplines (Siti Kotijah, 2010, 345-386). Enforcement of environmental law in the field is constrained by a number of factors, including inadequate human resources, inadequate infrastructure and stakeholder engagement. This can be seen from the enforcement legislation halting 15 (fifteen) forest fire cases in 2015 in the province of Riau (Kompas, 2016). A justice system, in particular the environment, which supports environmental governance in Indonesia is required to establish effective environmental law. In connection with the background outlined above, the problem identification in this paper is formulated, namely, How do you build environmental justice in the justice system in Indonesia?

\section{Research Methods}

The research used by the author is normative juridical (doctrinal). The data used in this study are secondary data, namely primary legal materials starting from the 1945 Constitution, Law Number 48 of 2009 concerning Judicial Power, Law Number 3 of 2009 concerning the Supreme Court, Law Number 49 of 2009 concerning General Courts, Law Number 32 of 2009 concerning Environmental Protection and Management and Law Number 18 of 2013 concerning Prevention and Eradication of Forest Destruction, secondary legal material in the form of journals, previous studies and relevant reference sheets. The method of legal research, according to Soerjono Soekanto, is "a scientific activity, which is based on certain methods, systematic and thinking, which aims to study one or several specific legal phenomena, by analyzing them. (I Gusti Ayu Ketut Rachmi Handayani, Lego Karjoko, Abdul Kadir Jaelani, 2019)

\section{Discussion}

\section{Urgency in the Development of Special Judicial Environments in Indonesia}

In accordance with the basic character of this positive law, Sunaryati Hartono sees that the 1945 Constitution was prepared as a means of social manipulation, with more commitment to the concept of law (C.F.G. Sunaryati Hartono, 1991, 53). As well as being decided by the environment or political structure of the making momentum, the positive legal character in its nature as a statutory regulation is also closely related to the moral and professional responsibilities of the legislative members themselves. Because the spirit of law that is developed is closely related to the lawmakers' vision, an outline of the role of lawmakers is important in the context of establishing democratic rule. Gardiner said lawmakers are not only obliged to adapt the law to this changed society, but they also have the opportunity to contribute to the shaping of changes in society. Therefore, politicians no longer merely obey changes in 
society but precede such changes instead.

Roeslan Saleh asserted in this connection that a just and prosperous and modern society which is the goal of national development is in fact an indirect creation of the legislators (Roeslan Saleh, 1979, 12). Environmental laws and regulations are sufficiently adequate in substance, as they already accommodate the interests of the community and the environment associated with the application in the field are still subject to limited competent human resources and inadequate infrastructure facilities. According to Prof. Subekti, the structure is an order or order, a whole composed of parts that are closely connected to each other, organized according to a plan or design, the product of writing in order to accomplish an objective. According to Sudikno Mertukusumo, the legal system is a complete order or unity consisting of parts or elements closely related to each other, namely the rules or declarations about what should be, so that the legal system is a normative structure (Eman Suparman, 2016, 36).

The Major Indonesian Dictionary (KBBI) concept of law enforcement has a very broad meaning that covers both preventive and oppressive aspects, in accordance with the conditions of Indonesia where elements of government are actively involved in raising public awareness of the law. Law enforcement according to Satjipto Rahardjo is a mechanism for the realization of legitimate wishes (Satjipto Rahardjo, 1983, 25). The legal interests alluded to here are those that are the thoughts of the lawmakers formulated in those rules. The way legislators' minds are formulated as illustrated in the rule of law also dictates how law enforcement is performed. And in essence, the law enforcement process resulted in the law enforcement officers themselves enforcing it. From this case, it can be said in a severe tone that the success or failure of law enforcers in carrying out their duties has actually started since the necessary legal regulations were made (Satjipto Rahardjo, 1983, 25). In Soerjono Soekanto 's view the law enforcement process is influenced by five (five) factors (Soerjono Soekanto, 2008,15 ). First, the factors which are legal or regulatory. Second, the law enforcement officers element, namely the parties involved in the lawmaking and compliance process which is linked to attitude issues. Third, the facility or facility factor which supports the law enforcement process. Fourth, cultural considerations, including the social atmosphere in which the law applies or is applied; concerns legal knowledge and compliance representing the actions of individuals. Fourth, cultural influences, including the correlation of life's work, imagination, and taste dependent on human initiative.

Meanwhile Satjipto Rahardjo, based on the degree of closeness to the process, differentiated various powerful elements in the law enforcement process, namely those which were rather far away and those which were rather nearby. On the basis of the closeness criteria, Satjipto Rahardjo distinguishes three (three) major elements involved in the law enforcement process (Satjipto Rahardjo, 2009, 23-24). Next, the law-making components cq. Legislature. Second, the law enforcement element cq. Police, Lawyers and Judges. And thirdly, elements of the environment which include private and social people. Jerome Frank, on the other hand, also spoke of various factors involved in the 
law enforcement process. In addition to the legal norms, some of these factors also include political , economic, moral prejudice, personal sympathy and antipathy (Lili Rasjidi, 1991, 51).

In Indonesian, the term law enforcement leads us to the idea that law enforcement is always coercive so that some argue that law enforcement is concerned only with criminal law. Law enforcement has a very broad meaning covering both preventive and authoritarian dimensions, suitable for Indonesia 's condition where government elements are actively involved in raising the legal awareness of the people. Conceptually, the essence and meaning of law enforcement lies in the work of harmonizing the relations of values set out in solid rules and attitude of action as a series of translations of the final stages of value to create, preserve and maintain peaceful social relationships. Regulation of environmental law is quite complex law enforcement because environmental law occupies a crossroads between the different fields of traditional legislation.

\section{Building Environmental Justice in the Justice System in Indonesia}

Enforcement of environmental law is the last link in the environmental policy planning arrangements cycle as follows : 1.). Gesetzgebung, 2). Standards Setting, 3). Permit to Give, 4). 5) Application. Strengthening laws. According to Mertokusumo, if only legal certainty is involved in law enforcement then the other elements are sacrificed. Likewise, if only the benefit is concerned, then it sacrifices legal certainty and justice. Therefore the three elements, namely certainty, expediency and justice, need to be compromised in the enforcement of environmental law. This means that all three have to be given proportionally balanced attention in handling it, although it is not always easy to do so in practice. In contrast to case with M. Daud Silalahi who said enforcement of environmental law includes compliance and enforcement that includes administrative law of the state, civil law and criminal law. Environmental Protection and Management Act No.32 of 2009 provides for three types of enforcement of environmental law, namely administrative, civil and criminal law enforcement.

Among the three forms of law enforcement available, the most significant law enforcement effort is considered to be administrative law enforcement. This is because the enforcement of administrative law is more geared towards efforts to avoid pollution and environmental damage. Additionally, administrative law enforcement also aims to punish those responsible for pollution and damage to the environment. Law enforcement is the process of efforts or the actual functioning of legal norms as guidelines for behavior in social and state-life relationships. Judging from the subject, a broad subyak can carry out law enforcement and can also be interpreted as enforcement efforts involving all legal subjects in any legal relationship. According to the topic, law enforcement can be interpreted as an effort by some law enforcement apparatuses to guarantee and uphold the law and law enforcement apparatus can use forced power in the law enforcement process (Kartono, 2009, 247-257). 
Paulus Lotulung (Hukumonline, 2002), who conveyed in a workshop that enforcement of environmental law in Indonesia is in fact still very demanding, also recognizes the problem of law enforcement that is still a concern. Citing his book, Mas Achmad Santosa, Paulus said there still had to be a struggle for a judiciary capable of producing quality judgements, apart from the influence of power and material rewards. The short cut is the establishment of a special judicial environment to improve everything out of the law enforcement apparatus. Aspects need to be seen at the court's location in the organization of judicial power in order to form an environmental court. Article 24 of the Constitution of 1945 stipulates that Indonesia 's judicial environment consists of general courts, religious courts, military courts, and state administrative courts. It is also possible to have special judicial bodies in each of such judicial settings, such as commercial courts, which are included in the general court system. It would be difficult to consider, on the basis of Article 24, that an environmental court with jurisdiction in civil, criminal and state administrative matters which is structurally outside the four judicial environments mentioned in the Constitution of 1945 will be unconstitutional. Pancasila is the philosophy of the Indonesian state that underlies the Indonesian people's lives and therefore the reform of the justice system must be in line with the Pancasila values (Tommy Leonard, 2016, 131-140).

The constitutional requirements on Indonesia's judicial system, namely Article 24, which includes an autonomous judicial body consisting of general courts, religious courts, military courts, and state administrative tribunals. It is also possible to have special judicial bodies in each of such judicial settings, such as commercial courts, which are included in the general court system. Independence in the exercise of power is needed for the exercise of independent judicial power. There must be no intervention from other branches of power, such as the executive or legislative branches and the existence of legal certainty and human rights safeguards regardless of gender, cultural background, economic conditions and political views (Adi Sulistiyono, 2006, 59-60). Lawrence M. Friedman sees that successful enforcement always demands that all components of the legal system function. Friedman 's view of the legal system is composed of three components (Lawrence M. Friedman, 1984, 16), namely the component of the legal structure, the component of the legal substance and the component of the legal culture. Legal structure is the torso, framework and eternal form of a system. The substance of the law (legal substance) is the actual rules and norms that institutions use, the reality, the behavior of the actors that the system observes.

Law culture (legal culture) is the ideas, attitudes, beliefs, hopes, and views on the law. Friedman also added a fourth component in its development which he called the component of legal impact. What is meant with this component of legal impact is the impact of a legal decision that is the object of the researchers' study. According to Roger Cotterrell, in connection with this legal culture, the concept of legal culture explains the diversity of ideas about law which exist in different societies and their position in the social order. These ideas explain legal 
practices, citizens' attitudes towards law and their willingness and unwillingness to file a case, and the relative significance of law in explaining broader thinking and behavior outside the practice and form of special legal institutions discourse. As such, variations in the legal culture can explain a lot about the differences in how legal institutions that appear to be the same in different societies can function (Mochtar Kusumaatmadja, 2013, 11).

As a statutory regulation, the substance of the law has been accepted as an official instrument that obtains aspirations to be developed, which is pragmatically oriented to deal with contemporary social issues. Law with such character is better known as the legal concept of law as Roscoe Pound's tool of social engineering, or mentioned in the terminology of Mochtar Kusumaatmadja as a law that functions as a means to help change society (Mochtar Kusumaatmadja, 2013, 18). As an emancipatory law the character of the law's responsiveness is often mentioned. Emancipatory laws indicate a democratic and egalitarian nature, i.e. laws that pay attention to efforts to protect human rights and provide greater opportunities for socially, economically and politically weak citizens to participate in all spheres of social life, nation and state. It is said that in societies which uphold the spirit of democracy there is responsive law. Responsive law shows the characteristic that law does not exist for the sake of the law itself, not for the sake of legal practitioners, nor is it to make the government happy, but the law does exist for the sake of the people in society (Max Weber in A.A.G. Peters and Koesriani Siswosoebroto, 1988, 483).

In Indonesia 's environmental justice system is consistent with Lawrence $\mathrm{M}$. Friedman 's theory that the success of law enforcement always requires all components of the legal system to function. In Friedman 's view, the legal system consists of three components (Lawrence M. Friedman, 1984, 16), namely the component of the legal structure, which is the apparatus of law enforcement agencies ranging from prosecutors, judges, police, public servant investigators (PPNS) ministries of the environment and forestry (forestry police, PPNS environment), component of the legal substance, Article 33 paragraph 3, which reawaits Water resource conservation is an instrument designed to create a good and healthy environment. The constitutional requirements on Indonesia's judicial system, namely Article 24, which includes an autonomous judicial body consisting of general courts, religious courts, military courts, and state administrative tribunals. Law No. 48 of 2009 on Judicial Power, Law No. 3 of 2009 relating to the Supreme Court, Law No. 49 of 2009 relating to General Courts, Law No. 32 of 2009 relating to Environmental Protection and Management, Law No. 05 of 1990 relating to the Conservation of Living Natural Resources a

The provisions in the Constitution relating to the judicial system in Indonesia, namely Article 24 which contains independent judicial powers consisting of general courts, religious courts, military courts and state administrative courts, where possible, it is necessary to amend the inclusion of environmental courts as part of the judicial system in Indonesia. Building an environmental justice system in Indonesia can begin with a general court special assembly that handles environmental cases and the judges panel has 
environmental integrity and competency. Other law enforcers, such as prosecutors and police, need to have integrity and enhance environmental competence in addition to the judges.

\section{Conclusion}

Based on the discussion above, it can be concluded that the urgency of the formation of environmental justice in Indonesia in accordance with the theory of Lawrence M. Friedman sees that the success of law enforcement always requires the functioning of all components of the legal system. The legal system in Friedman's view consists of three components, namely the legal structure component, namely the apparatus of law enforcement agencies ranging from prosecutors, judges, police, civil servant investigators (PPNS) to the ministry of environment and forestry (forestry police, PPNS environment ), the legal substance component, namely Article 33 paragraph 3 which reads "The earth and water and natural resources contained therein are controlled by the state and used for the greatest prosperity of the people" in article 28 it is said that every citizen has the right to an environment that is good and healthy conservation of water resources is an instrument for creating a good and healthy environment. Building an environmental justice system in Indonesia can begin with a special assembly in the general court that handles environmental cases and the panel of judges has environmental integrity and competence. In addition to judges, other law enforcers, such as prosecutors and police must have integrity and improve competence in the environmental field. Pancasila is the philosophy of the Indonesian state which underlies the life of the Indonesian people therefore the reform of the justice system must be in line with the values of the Pancasila.

\section{References}

Adi Sulistiyono, 2006, Krisis Lembaga Peradilan di Indonesia, Surakarta : UNS Press.

Ayu Dian Pratiwi, Pius Triwahyudi, "Jaminan Perlindungan yang Berkeadilan bagi Tenaga Kerja Difabel Akibat Kecelakaan Kerja”, Jurnal Bestuur, Vol 7, No 2 (2019).

C.F.G. Sunaryati Hartono, 1991, Politik Hukum Menuju Satu Sistem Hukum Nasional, Bandung: Alumni.

Eman Suparman, 2016, Sistem Peradilan di Indonesia Bahan Perkuliahan Program Doktor UNS, Surakarta.

Febry Wulandari, Waluyo Waluyo, "Efektivitas Pemanfaatan Dana bagi Hasil Cukai Hasil Tembakau dalam Bidang Kesehatan di Kota Surakarta Tahun 2018" Jurnal Bestuur, Vol 7, No 1 (2019). 
I Gusti Ayu Ketut Rachmi Handayani, Lego Karjoko, Abdul Kadir Jaelani, "Model Pelaksanaan Putusan Mahkamah Konstitusi yang Eksekutabilitas Dalam Pengujian Peraturan Perundang-Undangan di Indonesia”, Jurnal Bestuur, Vol 7, No 1 (2019).

Kartono, 2009, Penegakan Hukum Lingkungan Administratif Dalam UndangUndang Perlindungan dan Pengelolaan Lingkungan Hidup, Jurnal Dinamika Hukum, Vol.og No. 3, Purwekerto : FH UNSOED.

Lawrence M. Friedman, 1984, American Law: An invalueable guide to the many faces of the law, and how it affects our daily lives, New York: W.W. Norton \& Company.

Lego Karjoko , Zaidah Nur Rosidah I Gusti Ayu Ketut Rahmi Handayani. 2019. Refleksi Paradigma Ilmu Pengetahuan Bagi Pembangunan Hukum Pengadaan Tanah. Jurnal Bestuur Vol.VII, Issue.1, Agustus, 2019.1-14.

Abdul Kadir Jaelani, "Politik Hukum Putusan Mahkamah Konstitusi Nomor 36/PUU-X/2012 Tentang Pembubaran BP MIGAS: Upaya Mengembalikan Kedaulatan Negara Menuju Perlindungan HAM”, Jurnal Panggung Hukum, Volume 1, Nomor 1 Tahun 2015.

Liana Endah Susanti, "Economic Law Creation Beautiful Global Indonesia” Jurnal Bestuur, Vol 7, No 1 (2019).

Lili Rasjidi, 1991, Filsafat Hukum Apakah Hukum Itu?, Bandung: Remaja Rosdakarya.

Martin Roestamy, "Model Land Supply for Land Bank to House Application", Jurnal Bestuur, Volume 8, No. 1 (2020).

Max Weber dalam A.A.G. Peters dan Koesriani Siswosoebroto, 1988, Hukum dan Perkembangan Sosial (Buku I), Jakarta: Sinar Harapan.

Mochtar Kusumaatmadja di dalam Otje Salman dan Eddy Damian, 2013, KonsepKonsep Hukum dalam Pembangunan cet.4, Bandung: Alumni.

Nana Sudiana dan Hasmana Soewandita, 2007, Pola Konservasi Sumber Daya Air di Daerah Aliran Sungai Siak, Jurnal Alami Vol. 12 Nomor 1.

Najella Zubaidi, Regy Gusti Pratama, Sholahuddin Al-Fatih, "Legal Perspective on Effectiveness of Pre-Work Cards for Indonesian People”, Jurnal Bestuur, Volume 8, No. 1 (2020).

Nurfaika Ishak, Rahmad Ramadhan Hasibuan, Tri Suhendra Arbani, "Bureaucratic and Political Collaboration Towards a Good Governance System”, Jurnal Bestuur, Volume 8, No. 1 (2020).

Roeslan Saleh, 1979, Penjabaran Pancasila dan UUD 1945 Dalam Perundangundangan, Jakarta: Bina Aksara.

Rudy Iskandar Ichlas, "Questioning the Independence of Media Coverage in the 2019 Elections”, Jurnal Bestuur, Volume 8, No. 1 (2020).

Satjipto Rahardjo, 2009, Penegakan Hukum; Suatu Tinjauan Sosiologis ,Yogyakarta: Genta Publishing.

Siti Kotijah, 2010, Implementasi Prinsip-prinsip Kehutanan dalam Rangka Konservasi Kehutanan: studi kasus di Jawa Timur, Jurnal Magister Hukum, 
J.B. Vol. 8, Issue 2, December, 2020, page: 129-138 | DOI: 10.20961/bestuur.42774

Vol. 1 Nomor 2, Surabaya : Program Studi Magister Ilmu Hukum, Universitas Wisnuwardhana.

Soerjono Soekanto, 1984, Pengantar Penelitian Hukum.cet.2007, Jakarta : UI Press. , 2008, Faktor-Faktor yang Mempengaruhi Penegakan Hukum, Jakarta: Raja Grafindo Persada.

Triwanto Triwanto, Esti Aryani, "The Urgency of Granting Authority to Assess Corruption Justice Collaborators", Jurnal Bestuur, Volume 8, No. 1 (2020).

Tommy Leonard, 2016, Pembaharuan Sanksi Pidana Berdasarkan Falsafah Pancasila dan Sistem Hukum Pidana di Indonesia, Jurnal Yutisia, Edisi 95, Mei-Agustus 2016, FH UNS, Surakarta.

Zaidah Nur Rosidah, "Coherence of the Rules of Sharia Against Pancasila”, Jurnal Bestuur, Volume 8, No. 1 (2020). 